\title{
THE INTERVENTION AND RE-EVALUATION OF GENDER DISPARITY BY WOMEN CHARACTERS IN MACGOYE OLUDHE'S NOVEL COMING TO BIRTH
}

\section{Violet Nasambu Barasa}

School of Education, Department of Education Arts, Kabarak University

Cite this article:

Violet Nasambu Barasa (2021), The Intervention and Re-Evaluation of Gender Disparity by Women Characters in Macgoye Oludhe's Novel Coming to Birth. African Journal of Social Sciences and Humanities Research 4(4), 22 30. DOI: $10.52589 /$ AJSSHROCUAZB8I.

\section{Manuscript History}

Received: 30 May 2021

Accepted: 5 July 2021

Published: 21 Aug 2021

Copyright $\odot 2020$ The Author(s). This is an Open Access article distributed under the terms of Creative Commons AttributionNonCommercial-NoDerivatives 4.0 International (CC BY-NC-ND 4.0 ), which permits anyone to share, use, reproduce and redistribute in any medium, provided the original author and source are credited.
ABSTRACT: This paper examines the strategies employed by female characters to re-evaluate gender disparity in Macgoye's novel Coming to birth. Despite the different structures put in place to limit women's access to opportunities, the female characters in Coming to birth device ways out of such limitations thereby attaining some agency. Gender inequality is a phenomenon that has been in existence from time immemorial. In most societies across the world, gender inequality is entrenched in its social, cultural, political, historical and economical spheres that inform the workings of particular institutions. I also hasten to add that the manifestation of gender disparity varies from one region to another and therefore by analysis and discussion is largely informed by the primary text and relevant secondary sources consulted.

KEYWORDS: Gender Inequality, Agency, Strategies, Opportunities 


\section{INTRODUCTION}

This essay explores the strategies employed by female characters in Coming to Birth to exercise agency and emancipation. Cognizant of the patriarchal order that inform most of the happenings in the text, I posit that women employ a variety of strategies to interrogate and deconstruct patriarchal structures that have restricted their very own existence and position. In the main, the essay engages with how the female characters in the text question traditional patriarchal structures by disturbing and subverting practices forced on them on the basis of their sex. The essay is sub-divided into four thematic sections that together build up to demonstrate women as active agents of their lives as demonstrated in the analysis that follows below.

The first space that offers women emancipation in Coming to birth is religion. In most regions of the world such as Asian countries and Africa, religion often works to advance male chauvinism. This is informed by the fact that, in most religious groupings such as Islam, Roman Catholic among others, church leadership has been, for a long time, a domain for men. Therefore, like patriarchy, the church does not provide opportunities for gender equality where women can be given leadership positions. The gender discrepancy that informs church operations automatically position women congregants in the subordinate roles in matters such as church leadership. In this regard, one is inclined to argue that religion, it appears, forms part of the causes of gender disparity in the contemporary society. Gender disparity in religion has its origin in religious literatures available such as the Koran, Bible among others. Most religious teachings clearly spell out the domain for women and the domain for men hence each should work toward upholding these distinct spheres as God's own plan of things. Ndeda writes that despite the church being populated by women, they still play a marginal role in power structures.

Based on the foregoing, one is inclined to ask: how then does Christianity liberate women when women are not treated equally in the church? Are women truly free to have a choice in the church? This is open to debate since women are treated differently from one denomination to the other. Despite the above, what is clear is that the gender inequality trend in the church was and is still advocated in most denominations in the contemporary society. For instance, early missionary women in Africa advocated women's subordination to their husbands and taught African women vocational skills that confined them to the homes. This is articulated succinctly by Comaroff and Comaroff who point out that "the accomplishment of a missionary in Central Africa advocated for "the husband to be a jack-of-all-trades without doors and the wife to be a maid-of-all-work within" (1992, p. 48). Therefore, such teachings as observed by Camoroff and Camaroff (1992) heightens the gender disparity gap especially in Africa.

In effect, the confinement of women within the constructed private domestic space and the men in the public domains was an important aspect of Christian evangelism in Africa. This therefore worked to limit women further within patriarchal dictates. In this regard, the church teachings trajectory shaped subsequent events in the development of rules, rights, obligations and accomplishments by gender in most post-colonial societies. Macgoye, as a missionary herself in Africa, raises gaps and silences in Coming to Birth. For instance, is it possible for her to have gone against her missionary call by creating and depicting women in her text who remain single yet religion and especially the Anglican church, which Macgoye was working for, reveres the family and the marriage institution? 
I make haste to note that though the leadership in the church is male dominated, Macgoye uses the religious space deliberately to empower women from the subordinate position they occupy within the church. This is because within the precincts of the church, women congregants find freedom in choosing what they want in life and speaking to each other. Through speech, women are able to break the silence that marks their life within the domestic sphere. The freedom to speak and be listened to is an important aspect in attaining assertiveness, a strategy that then allows women to claim their voice. I note that speaking subsumes knowledge of what is spoken about. By women finding a space from which they could speak about their own experiences, the church, unconsciously, opened up opportunities that destabilized patriarchal advocacy for women silence and passive role in decision making.

In Coming to Birth, the Christian teachings alter the social, economic and cultural behaviour patterns as envisaged in the African traditional mould about women's position. For instance, one of the aspects that Christianity introduces in Coming to Birth is the issue of spinsterhood. In the text, we meet women such as Druscilla and Ahoya who opt to remain single because they want to work for the good Lord. A good example is Drusilla, the lady who examines Paulina when she is discharged from hospital during her first miscarriage. The narrative voice informs us that:

Then someone brought Drusilla, a saved sister who was a midwife and had felt the call of God to remain single and work at her profession, helping and witnessing to other women. Paulina found it hard to understand a woman who, though not very young, was still marriageable could make such a choice. In custom, there was no place for the unmarried. (Macgoye, 1986, p. 16)

The quotation above shows that through Christianity, the traditional value and worldview of women to marry is challenged. This is captured in Paulina's incomprehensibility of such practices since custom did not have space for them (Macgoye, 1986, p. 16). Paulina's views are based on how women are socialised into sustaining the very structures that oppress them throughout their lifecycle. Through spinsterhood, Macgoye interrogates traditional practices that socialise women into believing that they must get married. As such, Macgoye gives women the power of choice as far as their bodies and marriage is concerned.

Through this strategy, Macgoye contests the social stigma associated with spinsterhood by presenting women who chose not to enter into marriage as it is expected of them. By defying the dictates of patriarchy which socialise women to be wives in their lifetime, characters such as Ahoya and Drusilla regain control over their bodies and sexuality. I note that to a larger extent, women's sexuality informs the gender inequality that they experience in their lives. Therefore, by opting not to get married, Ahoya and Druscilla claim the power of their sexuality and autonomy over their identity as women. In most patriarchal societies, marriage especially of girls is a decision made by parents and in particular the male members of the family. In Coming to birth for instance, Paulina's marriage to Martin is decided by her father and that was final.

Initially, Paulina cannot comprehend spinster lifestyle because as a person and a woman in this case, she has been socialized to believe that every woman must get married and that is where they belong in the society. Since custom does not offer space for spinsterhood, then Christianity proves to be a fruitful site for such women who opt not to get married. Though, traditionally, "respectability of such women was massively reduced by their unmarried 
status" (Kanago, 2005, p. 52), Macgoye shows that Christianity is a strategy that women can harness to break free from cultural structures that infringe on their choices. Accordingly, through spinsterhood, women gain power over their bodies in choosing what is good for themselves.

Therefore, Ahoya and Drusilla have adopted solutions in their lives, by violating conventional norms to intractable problems created by the patriarchal society. Kanogo observes that "women's construction of the self as they accessed new normative and special options in colonial Kenya became important markers of women's agency" (2005. p. 2). Therefore, based on Kanogo's observation, I point out that Ahoya's and Drusilla's choice to claim their sexuality demonstrate women's agency and emancipation. According to Reynolds (2003), a woman's sexuality is what defines her as a woman and defines her position in the society.

Macgoye deliberately employs spinsterhood to give voice and immediacy to issues dealing with women's experiences in the society. Marriage is a structure designed and placed on women as a form of defining one's identity by the society. Therefore, in choosing not to get married, Ahoya and Drusilla subvert this definition thereby claiming agency. They become actors in the course of their lives rather than becoming passive recipients and implementors of what society hands them. These women explicitly redefine their social status thereby plunging the traditional practices into question. By denouncing victimhood and oppression of patriarchy, Ahoya and Druscila have, in the words of Nnaemeka, "chosen to act and not be crushed or silenced" (1997, p. 4).

In addition to the above, education has also been portrayed in the text as an avenue through which women attain agency. In most societies across the world, education has been advocated as one of the ways for a society's development. However, the introduction of Western education in colonial Africa was done on a discriminatory basis where girls were not educated to the same level as boys. This practice intertwined with traditional patriarchal structures confined women to homes thereby reducing them to subordinate roles. However, such practices have been contested by pointing out that access basic education for girls offer some form of independence in life. Education allows women to make independent choices aimed at biological, psychological and sociological rebirth of one's own emancipation. This is well captured in Paulina's unrelenting desire to access education despite having been denied this chance at the age of sixteen when she is married off.

Paulina's determination and self- will to go to Home Craft College as a married woman is a challenge to a society that give boys priority to education over girls. The practice of denying education to girl children is not unique to Paulina as shown in the primary text but has been demonstrated in a number of literary texts across the world. For instance, we have the case of Tambu in Dangarembga's Nervous conditions, Gathoni in Ngugi wa Thiong'o and Ngugi wa Mirri's I will marry when I want or even Ruku in Kamala Markandaya's Nectar in a sieve. In Nervous conditions, Mashingayi tells Tambu that a girl does not need an education to prepare the husband's food and in I will marry when I want, Wangeci tells Gathoni that if you want a bed, wait until your husband buys you one.

Mashingayi and Wangeci's sentiments capture the embedded gender disparity that mark women's access to education. Such a worldview predisposes women to a culture of dependency where the husband has to provide all. As such, when Paulina decides to go back 
to school, she throws a spanner into the culture of dependence. What Paulina accomplishes eventually demonstrates that women can equally be financially successful if given education opportunities. In this regard, if women and men are provided with equal opportunities and both are allowed to compete fairly, there is nothing inherent in women that should lower the level of performance and success. The obstacles built around women in patriarchal inclined societies are mere beliefs depicting women as the weaker sex, both physically and intellectually. The denial of girls to access education is a theorem encapsulated in traditional structures that has been deconstructed by Paulina in Coming to birth.

Boyce points out that "[a] character's ability to define herself is shaped both by her understanding of the boundaries by which society circumscribes her and by her ability to transcend those boundaries and attain self-actualisation while remaining nonetheless within her society" (1993, p. 336). Paulina therefore stands as a good example of such a woman, who creates new spaces for herself in her community without threatening the basis of Kenyan society based on her knowledge of what hinders her emancipation. In creating a new awareness about womanhood, Macgoye's Coming to Birth moulds a new woman capable of righting what is wrong. This confirms Stegeman's (1974, cited in Frank 1987) argument that:

The New Woman represents a theory of personhood where the individual exists as an independent entity rather than in her kinship relations, where she has a responsibility to realize her potential for happiness rather than to accept her role, where she has indefinable value rather than quantitative financial worth, and where she must reason about her own values rather than fit into a stereotyped tradition. (p. 17)

Stegeman's argument is a philosophical interrogation of the institutionalisation of male dominance and patriarchal interests that are detrimental to women's emancipation. Through Paulina, Macgoye, underscores the need for individual women to break loose from the chains limiting them and seek change in the system in which they live.

The earnings that Paulina is paid at the Home Craft College are generated into developing her house and in the upkeep of her mother-in-law. The writer thus portrays the woman as someone capable of handling financial issues better that men if read against Martin who is always without money and sharing rooms with relatives despite being married and employed. $\mathrm{He}$ is always retrogressing while Paulina's financial stability matures with time. Paulina's resourcefulness is challenge to women to access education at all levels of their age and status. For women to emancipate themselves, they should "renegotiate [traditional] beliefs and equip themselves with knowledge for effective resistance and participation in societal transformation" (Nnaemeka, 1997, p. 21) which is captured by Paulina's determination to access education regardless of her status as a married woman.

Paulina's economic success offers her an inner stability that results from her ability to be selfsufficient and be able to support her extended family as well as herself. By negotiating economic parity with the male, women in the embodiment of Paulina demonstrate their capacity for independent action. Paulina's economic stability leads to a personal reconstruction of the dispersed female self, leading to her physical beauty. For instance, we are told that at the Home Craft College, "women found her happier and thought she was beginning to enjoy the fruits of her labours" (Macgoye, 1986, p. 62). Money therefore offers Paulina happiness that was deficient when she was reliant on Martin. 
The text also portrays the rural/urban spaces as a possible ingredient in attaining women agency. The rural and urban spaces are depicted as gendered as seen in most African literary works. The rural is considered a place for women while the city is a space for men. This is a notion that was propagated by the colonialist to ensure upholding of morality. This is because the society considered women who went to town as immoral and for this reason, majority of women remained in rural areas as their men sought employment in urban centers. Such as social order led to women's subordination since they were forced to rely on their men financially. Stratton argues that the urban-rural dichotomy contributed to the process of "women's economic marginalisation by relegating them to the rural economy, which in practice meant subsistence farming" (Stratton, 1994, p. 16). The division of the two spaces puts the woman in a dilemma because if she chooses to go to town, she will be "labeled a prostitute or singled out as a case of national indiscipline" (Stratton, 1994, p. 17) and if she remains in the village as a housewife, she is economically marginalised.

In the first chapter of the text, Macgoye presents Paulina as a very naïve rural girl who finds life in the big city completely different from the rural life she was used to. She is startled with almost everything that she encounters in the city. For instance, she is surprised to find out that in the city, people are individualistic and pass each other without greetings and that she is the only one giving way for them to pass on the streets. The narrative voice tells us that, Paulina "felt that she must be the one to give way whenever she came face to face with someone hurrying in the same direction" (Macgoye, 1986, p. 3). Macgoye thus depicts the city as a chaotic place in comparison with the rural area where people are orderly. However, I argue that these events that Paulina experience on her arrival in the city marks the beginning of her growth.

Therefore, for Paulina to be integrated and assimilated into the urban lifestyle, she has to adjust and behave like people in the chaotic city. It is instructive to point out that for Paulina, this leads to a clash of dictates since she has carried her cultural practices and baggage to the city where she finds some of these practices not of substance. Since the urban setting is considered modern and the rural traditional, Paulina has to subvert some of the traditional dictates in order to survive in town since tradition can no longer hold. For instance, when Paulina is in intense pain prior to her first miscarriage, she is reluctant to tell Martin because it was against custom to tell her husband that she is expectant instead she should let the pregnancy show itself (Macgoye, 1986, p. 9).

The belief that women should stay in the rural areas and cultivate crops for their families is meant to restrict women from being exposed to the outside world out of their homes. Paulina in a flashback tells us that her father used to work in Mombasa on a sisal farm and she had never been there, nor had her mother, and she had very little idea of what his work was (Macgoye, 1986, p. 61). Macgoye interrogates these restrictions that require women to remain in the rural while their husbands are away in urban areas working by allowing women to migrate and venture in towns. The younger generation through Paulina, Rachel, and Amina among others are able to stay in urban centres and it is through venturing the urban space that they are able to learn and redefine themselves. Rachel sells Mandazi to supplement the husband's money; Amina is a landlady while Paulina begins her journey to financial independence, first by crocheting and then her eventual admission to the Home Craft College. They, therefore, prove that the urban space is resourceful for women's emancipation and an avenue toward economic power. 
In the cities, women are able to learn how to negotiate their life and how to survive in the changing socio-cultural, political and economic times. As her country moves toward independence, Paulina manages to achieve a kind of independence as well. This is seen when she accepts a job which requires her to stay away from home. In this regard, this is a step that allows her to grow beyond the traditional circle where a woman is supposed to stay in the home. Therefore, the urban space comes out as a space that offers women a chance to prove their potentiality and independence. Macgoye also demonstrates that despite the city presenting challenges to its inhabitants, it is also a place where women can as Amina puts it "take what comes and make the best out of it" (Macgoye, 1986, p. 146). It is because of Paulina's encounter with the city that she decides to go to the college. The city therefore becomes an eye opener for women's empowerment, a social order lacking in the rural setup where women are restricted to the home.

The traditional practices and beliefs among the Luo community is also a site for contestation in as far as gender parity is concerned. It is a fact that most of the societies around the world have cultural practices that have to be respected. However, Macgoye in an effort to recreate the female figure, contests traditional practices by showing that not everything in traditional culture should be followed blindly. The society, according to her, should only take what is good from tradition and leave out what is detrimental for its own advancement. For instance, when Paulina's father dies, "no one expected her mother to tear her clothes off in farewell to the body of her husband, as used to be the custom (Macgoye, 1986, p. 85).

Tradition can be described in the words of Ojo-Ade (cited by Esonwanne in Nnaemeka ,1997, p. 82) as the "established order of the past and the exigencies of the present". Much of tradition, as presented in Macgoye's text, represents specifically the abuses, exploitation, and oppression of women in Kenyan society. I also note that tradition is not uniform in Africa, and unfortunately, most people in or outside Africa see tradition as something rigid and static. Tradition is constantly changing, though not all aspects of tradition are mutant. It varies also from one African community to another. The traditional structures that subordinate women are advanced through the processes of gender socialisation which connects infidelity and heroism to males and associates the traditional roles of wife and mother to females. The ensuing gender asymmetry conceived, internalised and borne out of this need not be over emphasised since it speaks a lot about how people behave in the society in relation to their gender.

The society takes advantage of the biological differences of the sexes to validate the establishment of gender categories that in turn have been the bases of ingrained gender bias. According to Odhiambo, "female members in societies that have a tradition of patriarchal dominance always find themselves burdened with several restrictions, prescriptions, limitations and other such encumbrances solely on the basis of gender" (Odhiambo, 2001, p. 45). For instance, given Paulina's social status as a childless woman in the society, she has to accept Martin's infidelity since it is perceived to be normal. This is something decided for her and nothing can be done about it. The same custom allows women to have extra marital relations in case the marriage is not fulfilling like Paulina's case. Like Martin, Paulina takes advantage of traditional prescription of seeking sexual fulfilment outside marriage by engaging in extra marital affair with Simon. However, I argue that this practice should be discouraged for the establishment of happy and decent families. Macgoye at this point is sympathetic to some practices which seems "normalised" in the society. 
It is worth noting that Paulina decides to have this relationship with Simon when Martin's absence and long stay in the city becomes prolonged. We are told that "she was a married woman denied a married woman's rights and respects, in custom she should seek a child where she could. She had the right therefore to have another man to fulfil her sexual desires" (Macgoye, 1986, p. 54, emphasis added). Infidelity on the woman's part is, hereby, portrayed as a way of confronting male domination and wayward behaviour. Paulina negotiates sex out of necessity which is aimed at filling the gap created by her husband who is having illicit relationships with other women back in Nairobi. This is a good example of female subordination as a result of tradition and culture which Macgoye depicts as acceptable.

On learning about Paulina's infidelity, Martin does not blame himself for creating Paulina but comes back home, beats her up and denounces her as his wife. Martin thus is 'disciplining' Paulina to bring her back to the prescribed expectations of women in the society. The act of violence against women then denotes and emphasises the submissive and inferior role carved for the African woman in the society. Martin disregards the fact that, he too is keeping a mistress back in the city and this leads to their separation. The author satirises the social set up that privileges men to indulge in wayward behaviours while for women it is abominable. Paulina's behaviour is aimed at restoring order in the society by showing that what the two: Martin and Paulina, indulge in is bad and should not only be blamed on the woman but is a challenge for the society to change their outlook and reconstruct its structures. When Martin beats Paulina, he is just exercising the power that patriarchy has bestowed to him so that he can control Paulina's life. The woman's sexuality and body is, thus, controlled by men who use it to gratify themselves as seen in Martin's action.

By refusing to comply with her husband's expectations as a married woman, Paulina subverts an age-old tradition that silences women's feelings about their own bodies. She seeks to create a space within which African women can protest the subjugation of their bodies by men who see women's bodies and sexuality as a right that belongs to them for consumption. Paulina, therefore, represents women's unrelenting quest for justice that goes right to the core of male egocentrism. Martin's behaviour borders on the readings of male superiority and female subordination evident in most patriarchal societies. In challenging the requirement of remaining faithful in her marriage, Paulina is fighting to eliminate the root cause of women's oppression perpetuated by men without any shred of remorse.

\section{CONCLUSION}

This paper has analysed the strategies employed by female characters in Macgoye's Coming to birth novel in attempt to attain agency as a way of initiating change. Accordingly, it has made an attempt to show that women are capable of initiating change by breaking the silence and patriarchal structures put in place to make them docile. In the course of the analysis, the paper explored the different ways individual women characters employ to liberate themselves from societal structures that limit their emancipation. It emerged that it is only through women's own initiative that they can put an end to patriarchal structures that subjugate them. 


\section{REFERENCES}

Boyce, C.D., \& Graves, A. A. (Eds.). (1986). Ngambika: Studies of women in African iterature. Trenton: Africa World Press.

Carroll, D. (2001). "Book Review" in Black issues, Vol.3 Issue2.

Comaroff, J., and Comaroff, J. (1992). "Home-Made Hegemony: Modernity, Domesticity and Colonialism in South Africa", in Hansen. K. (Ed.). African encounters with domesticity. New Brunswick: Rutgers University Press.

Dangrembga, T. (1988). Nervous conditions. Harare: The Women Press.

Frank, K. (1987). 'Women without men: The feminist novel in Africa' in African Literature Today 15, 14-34.

Kanogo, T. (2005). African womanhood in colonial Kenya: 1900-50. Nairobi: East Africa Educational Publishers.

Macgoye, O. M. (1986). Coming to birth. London: Heinemann.

Markandaya, K. (1954) Nectar in a sieve. New Delhi: G. P. Putnam's Sons,

Ndeda M.A.J (1997). “The Women's Subordination in African Independence Churches: The Case of Nomiya Luo Church". The Eastern African Journal of Historical and Social Sciences Research, Vol. 1.

Nnaemeka, O. (1997). The Politics of (M)othering: Womanhood, identity and resistance in African literature. London: Routledge.

Odhiambo, T. (2001). Interrogating History and Restoring Agency to Women in TheRiver and the source by Margaret Ogola. MA Thesis, University of the Witwatersrand.

Reynolds, H., \& Nancy, R. (2003). Woman Today; A celebration: Fifty Years of South African Women. Cape Town: Kwela Books.

Stratton, F. (1994). Contemporary African literature and the politics of gender. London: Routledge.

Wa Thiong'o, N., \& Wa Miiri, N. (1982). I Will marry when I want. Oxford: Heinemann. 